\title{
KEARIFAN LOKAL BERBASIS ISLAM DALAM PELESTARIAN LINGKUNGAN HIDUP
}

\author{
Sulaiman Alqomayi \\ IAIN Walisongo Semarang \\ Jl. Prof. Dr. Hamka Km.1, Ngaliyan Semarang \\ E-mail: alkumayi97@yahoo.co.id \\ HP. +62-81390523366
}

Abstract: The disasters that are related to heavy rain such as flood, landslide and dry climate especially in Central Java are problems which need solutions. This article tries to explore the myth to preserve water resource as a local wisdom in Sempor society in Kebumen regency. This article uses Homo Ecologus and Cultural Identity approach to understand the object. Based on that opinion, it is found that the myth is rooted in the value and point of view of Sunan Buyut Saringan who always emphasized on thankfulness of everything that has been given by God.

Abstrak: Bencana yang berhubungan dengan hujan, seperti banjir dan tanah longsor, kekeringan, termasuk yang terjadi termasuk di wilayah Jawa Tengah, merupakan problem yang membutuhkan penangan. Tulisan ini mengeksplorasi mitos sebagai kearifan lokal yang ada dalam masyarakat Kecamatan Sempor Kabupaten Kebumen dalam upaya melestarikan sumber daya air. Tulisan ini menggunakan pandangan Homo Ecologus dan Cultural Identity untuk memahami objek. Dari pandangan itu, ditemukan bahwa mitos masyarakat Kecamatan Sempor Kabupaten Kebumen berakar pada nilai dan pandangan hidup dari Sunan Buyut Saringan yang selalu menekankan syukur atas kenikmatan yang telah diberikan Tuhan kepada mereka melalui slametan.

Kata Kunci: Kearifan Lokal, Islam, Slametan, Homo Ecologus, Cultural Identity.

\section{A. Pendahuluan}

Banjir dan kekeringan yang akhir-akhir ini sering melanda berbagai wilayah di Jawa Tengah membuktikan adanya persoalan lingkungan yang tengah terjadi. Kondisi tersebut tidak lepas dari perbuatan manusia yang cenderung merusak alam, misalnya pembalakan dan perambahan hutan, serta 
penambangan pasir dan batu di sekitar daerah aliran sungai. Kondisi tersebut diperparah oleh perubahan iklim dunia (global warming).

Kabupaten Kebumen merupakan salah satu daerah yang ikut merasakan dampak kerusakan lingkungan khususnya kerusakan Daerah Aliran Sungai (DAS). Banjir besar yang pernah melanda Kebumen antara lain disebabkan air hujan yang tidak tertampung lagi oleh sungai sehingga meluap ke perkampungan. Berdasarkan data Balai PSDA Probolo, kerusakan yang terjadi di DAS Telomoyo yang masuk dalam wilayah Kabupaten Kebumen telah menyebabkan kapasitas sungai untuk menampung air menjadi sangat berkurang. Penambangan pasir dan batu oleh penduduk serta penggerusan tebing sungai semakin menambah parah kondisi di daerah tersebut. Kondisi tersebut masih diperparah oleh banyaknya perambahan hutan sehingga tidak bisa lagi menahan air hujan. Akibatnya pada saat hujan lebat, air langsung mengalir ke daerah yang lebih rendah, dalam hal ini sungai-sungai di DAS Telomoyo. Berdasarkan data Balai PSDA Probolo, kerusakan terparah Sungai Telomoyo berada di Sub DAS Kemit.

Kondisi di atas juga disebabkan kegiatan pertanian yang kurang ramah lingkungan dan gundulnya hutan di daerah penampung air (catchment area). Hal ini mengakibatkan erosi yang terjadi di sepanjang aliran sungai tersebut semakin parah. Menanggapi situasi ini pada tahun 2003-2004, Pemerintah Provinsi Jawa Tengah melalui Balai Pengelola Sumber Daya Air (PSDA) Probolo melaksanakan kegiatan pilot project konservasi sumber daya air di Sub-Sub DAS Kalong dan DAS Kemit di Kabupaten Kebumen. Konsep pemberdayaan masyarakat sekitar DAS diterapkan pada tiga desa dampingan di sub-sub DAS tersebut. Pelibatan masyarakat menjadi agenda penting dalam proyek tersebut. Setiap kegiatan yang dilakukan merupakan hasil kesepakatan antara masyarakat dengan pemerintah. Hasil dari kegiatan tersebut cukup menggembirakan, berangsur-angsur perilaku masyarakat terhadap lingkungan DAS berubah menjadi lebih baik. Peran masyarakat dalam pengelolaan DAS tidak hanya sebagai penerima manfaat, namun juga sebagai pemrakarsa pelaksanaan serta penjaga kelestarian DAS.

Kegiatan yang bersifat fisik dan usaha peningkatan pendapatan masyarakat tentu saja belum cukup untuk melestarikan sumber daya air. Perubahan perilaku yang berangkat dari kesadaran masyarakat untuk berpartisipasi aktif dalam pelestarian lingkungan tent unya dibutuhkan, dan yang paling relevan dalam konteks ini adalah kearifan lokal (local wisdom) yang hidup di sekitar DAS Telomoyo di Kabupaten Kebumen dalam upaya mereka untuk melestarikan sumber daya air mereka. 
Tulisan ini bertujuan mengeksplorasi kearifan lokal, baik berupa mitos, kesepakatan, maupun norma yang berbasis pada adat dan ajaran agama Islam yang ada pada masyarakat Kecamatan Sempor Kabupaten Kebumen dalam upaya mereka melestarikan sumber daya air yang ada di lingkungan mereka.

\section{B. Pengertian Kearifan Lokal (Local Wisdom)}

Manusia dikenal sebagai makhluk multidimensi, salah satunya adalah sebagai homo ecologus (makhluk lingkungan) (Odum, 1983). Sebagai homo ecologus, manusia merupakan bagian dari ekosistem yang memiliki kecenderungan untuk selalu mencoba mengerti akan lingkungannya. Manusia bahkan cenderung untuk bereaksi terhadap pengertiannya tentang lingkungan dibandingkan dengan reaksinya terhadap lingkungan itu sendiri. Kecenderungan seperti ini menjadi salah satu ciri utama manusia sebagai makhluk berakal sehat (Abdillah, 2001: 1-2). Salah satu tanda dari akal yang sehat itu adalah kearifan yang melekat dalam dirinya. Kearifan itu terbentuk bisa saja karena merupakan produk lingkungan hidup sehingga melahirkan sebuah kearifan yang bersifat lokalitas. Berkaitan dengan ini kemudian memunculkan kearifan lokal (local wisdom) yang sebenarnya mengandung nilai-nilai luhur yang jika diberdayakan justru mampu menanggulangi krisis lingkungan.

Dalam pengertian kamus, kearifan lokal (local wisdom) terdiri dari dua kata: kearifan (wisdom) dan lokal (local). Local berarti setempat, sedangkan wisdom (kearifan) sama dengan kebijaksanaan. Secara umum, local wisdom (kearifan setempat) dapat dipahami sebagai gagasan-gagasan setempat (local) yang bersifat bijaksana, penuh kearifan, bernilai baik, yang tertanam dan diikuti oleh anggota masyarakatnya. Irianto (2010: 6), memberikan penjelasan mengenai kearifan lokal sebagai berikut:

"Kearifan lokal sering dikonsepsikan sebagai kebijakan setempat (local wisdom), pengetahuan setempat (local knowledge) atau kecerdasan setempat (local genius). Kearifan lokal adalah sikap, pandangan, dan kemampuan suatu komunitas di dalam mengelola lingkungan rohani dan jasmaninya, yang memberikan kepada komunitas itu daya-tahan dan daya tumbuh di dalam wilayah dimana komunitas itu berada. Dengan kata lain, kearifan lokal adalah jawaban kreatif terhadap situasi geografis-geopolitis, historis, dan situasional yang bersifat lokal. Kearifan lokal adalah pandangan hidup dan ilmu pengetahuan serta berbagai strategi kehidupan yang berwujud aktivitas yang dilakukan oleh masyarakat lokal dalam menjawab berbagai masalah dalam pemenuhan kebutuhan mereka".

Selain itu, dalam disiplin antropologi dikenal istilah local genius. Local genius ini merupakan istilah yang mula pertama dikenalkan oleh Quaritch 
Wales. Para antropolog membahas secara panjang lebar pengertian local genius ini (Ayatrohaedi, 1986: 15). Local genius adalah juga cultural identity, identitas/ kepribadian budaya bangsa yang menyebabkan bangsa tersebut mampu menyerap dan mengolah kebudayaan asing sesuai watak dan kemampuan sendiri (Ayatrohaedi, 1986: 18-19).

Unsur budaya daerah potensial sebagai local genius karena telah teruji kemampuannya untuk bertahan sampai sekarang. Ciri-cirinya adalah mampu bertahan terhadap budaya luar, memiliki kemampuan mengakomodasi unsurunsur budaya luar, mempunyai kemampuan mengintegrasikan unsur budaya luar ke dalam budaya asli, mempunyai kemampuan mengendalikan, dan mampu memberi arah pada perkembangan budaya (Ayatrohaedi, 1986: 40-41).

Gobyah (2008, balipos.co.id) dalam "Berpijak pada Kearifan Lokal”, mengatakan bahwa kearifan lokal (local genius) adalah kebenaran yang telah mentradisi atau ajeg dalam suatu daerah. Kearifan lokal merupakan perpaduan antara nilai-nilai suci firman Tuhan dan berbagai nilai yang ada. Kearifan lokal terbentuk sebagai keunggulan budaya masyarakat setempat maupun kondisi geografis dalam arti luas. Kearifan lokal merupakan produk budaya masa lalu yang patut secara terus-menerus dijadikan pegangan hidup. Meskipun bernilai lokal, tetapi nilai yang terkandung di dalamnya dianggap sangat universal.

Sementara itu, Geriya (2008, balipos.co.id) dalam "Menggali Kearifan Lokal untuk Ajeg Bali" mengatakan bahwa secara konseptual, kearifan lokal dan keunggulan lokal merupakan kebijaksanaan manusia yang bersandar pada filosofi nilai-nilai, etika, cara-cara, dan perilaku yang melembaga secara tradisional. Kearifan lokal adalah nilai yang dianggap baik dan benar sehingga dapat bertahan dalam waktu yang lama dan bahkan melembaga. Kearifan lingkungan atau kearifan lokal masyarakat sudah ada di dalam kehidupan masyarakat semenjak zaman dahulu mulai dari zaman pra-sejarah hingga saat ini. Kearifan lingkungan merupakan perilaku positif manusia dalam berhubungan dengan alam dan lingkungan sekitarnya yang dapat bersumber dari nilai-nilai agama, adat istiadat, petuah nenek moyang atau budaya setempat, yang terbangun secara alamiah dalam suatu komunitas masyarakat untuk beradaptasi dengan lingkungan di sekitarnya. Perilaku ini berkembang menjadi suatu kebudayaan di suatu daerah dan bertahan secara turun-temurun.

Secara umum, budaya lokal atau budaya daerah dimaknai sebagai budaya yang berkembang di suatu daerah, yang unsur-unsurnya adalah budaya sukusuku bangsa yang tinggal di daerah itu. Dalam pelaksanaan pembangunan berkelanjutan oleh adanya kemajuan teknologi, membuat orang lupa pentingnya tradisi atau kebudayaan masyarakat dalam mengelola lingkungan. 
Seringkali, budaya lokal dianggap sudah ketinggalan di abad sekarang ini sehingga perencanaan pembangunan seringkali tidak melibatkan masyarakat.

Berkaitan dengan 'urf, Pikiran Rakyat terbitan 6 Maret 2003 menjelaskan bahwa tentang kearifan berarti ada yang memiliki kearifan (al-'āddah alma'rifah), yang dilawankan dengan al-‘āddah al-jāhiliyyah. Kearifan adat dipahami sebagai segala sesuatu yang didasari pengetahuan dan diakui akal serta dianggap baik oleh ketentuan agama. Adat kebiasaan pada dasarnya teruji secara alamiah dan niscaya bernilai baik karena kebiasaan tersebut merupakan tindakan sosial yang berulang-ulang dan mengalami penguatan (reinforcement). Apabila suatu tindakan tidak dianggap baik oleh masyarakat, maka ia tidak akan mengalami penguatan secara terus-menerus. Pergerakan secara alamiah terjadi secara sukarela karena dianggap baik atau mengandung kebaikan. Adat yang tidak baik akan hanya terjadi apabila terjadi pemaksaan oleh penguasa. Bila demikian, maka ia tidak tumbuh secara alamiah, tetapi dipaksakan.

\section{Kearifan Berbasis Islam dalam Pelestarian Sumber Daya Air}

Di samping kearifan yang bersandar pada adat, terdapat juga kearifan yang bersandar pada ajaran-ajaran agama. Kearifan yang didasarkan pada ajaran agama yang telah terbentuk, dan diimplementasikan secara terus-menerus dalam kehidupan masyarakat dapat membentuk sebuah karakter yang disebut religius. Menurut R. Stark dan C.Y. Glock (1968) ada empat dimensi yang melekat dalam keberagamaan, yaitu:

\section{Dimensi Ritual}

Dimensi ritual adalah aspek yang mencermati seseorang melakukan kewajiban ritualnya dalam agama yang dianut. Misalnya, pergi ke tempat ibadah, berdoa pribadi, berpuasa, dan lain-lain. Dimensi ritual ini merupakan perilaku keberagamaan yang berupa peribadatan yang berbentuk upacara keagamaan. Pengertian lain mengemukakan bahwa ritual merupakan sentimen secara tetap dan merupakan pengulangan sikap yang benar dan pasti. Perilaku seperti ini dalam Islam dikenal dengan istilah maḥahah, yaitu meliputi salat, puasa, haji, dan kegiatan lain yang bersifat ritual, merendahan diri kepada Allah dan mengagungkannya.

\section{Dimensi Ideologis}

Dimensi ini mencermati tingkatan seseorang dalam menerima hal-hal yang bersifat dogmatis dalam agamanya. Misalnya, menerima keberadaan Tuhan, malaikat dan setan, surga dan neraka, dan lain-lain. Dalam konteks 
ajaran Islam, dimensi ideologis ini menyangkut kepercayaan seseorang terhadap kebenaran agama-agamanya. Semua ajaran yang bermuara dari al-Qur'an dan Hadis harus menjadi pedoman bagi segala bidang kehidupan. Keberagaman ditinjau dari segi ini, misalnya mendarmabaktikan diri terhadap masyarakat yang menyampaikan amar ma'rūf nahy munkar dan amaliah lainnya dilakukan dengan ikhlas berdasarkan keimanan yang tinggi.

\section{Dimensi Intelektual}

Dimensi intelektual mencermati seseorang dalam mengetahui, mengerti, dan paham tentang ajaran agamanya, dan dalam melakukan aktivitas untuk semakin menambah pemahamannya. Dimensi intelektual ini menunjukkan tingkat pemahaman seseorang terhadap doktrin-doktrin agama tentang kedalaman ajaran agama yang dipeluknya. Kegiatan itu dapat dilakukan melalui mengikuti seminar keagamaan, membaca buku agama, dan lain-lain. Secara lebih luas, dimensi intelektual ini memiliki indikator sebagai berikut:

a. Ilmu yang dimiliki seseorang akan menjadikannya lebih luas wawasan berpikirnya sehingga perilaku keberagamaan akan lebih terarah;

b. Dia akan lebih memahami antara perintah dan larangan dan bukan sekadar taklid buta;

c. Dengan ilmu pengetahuan, seseorang bisa menyingkap betapa besar dan megah ciptaan Tuhan dan betapa lemahnya hamba-hamba-Nya. Semakin banyak ilmu yang dimiliki maka semakin mampu manusia memahami alQur'an maka imannya semakin kuat; dan

d. Melalui argumen yang kuat, seseorang memperoleh pengetahuan agama terutama tentang wujud Tuhan, kehidupan kekal di akhirat, dan pengetahuan lainnya (Nasution, 1989: 120).

\section{Dimensi Pengalaman}

Dimensi ini mencermati tentang seseorang yang pernah mengalami pengalaman yang merupakan keajaiban dari Tuhannya. Misalnya, merasa doanya dikabulkan, merasa diselamatkan, dan lain-lain. Dalam kaitan religiositas dengan pelestarian lingkungan, termasuk di dalamnya adalah pelestarian sumber daya air, maka tidak ada satu ajaran agama pun yang tidak mendukung pelestarian alam. Islam, misalnya, memandang bahwa segala sesuatu diciptakan secara seimbang dan teratur; seperti pengaturan garis edar tata surya di angkasa raya, sehingga tidak terjadi berbent uran antara planet satu dengan planet lainnya, pengaturan energi di alam raya, termasuk di dalamnya pengaturan air melalui siklus hidrologik. 
Air memiliki posisi sentral dalam kehidupan. Semua organisme hidup, baik besar maupun kecil, membutuhkan air. Tanpa air, maka tidak akan ada yang bisa hidup. Allah SWT berfirman dalam Q.S.22:30: "Dan telah aku jadikan dari air segala sesuatu hidup, tidakkah mereka beriman?”. Dalam ayat yang lain, Allah SWT menyatakan bahwa manusia diciptakan dari air. Allah berfirman dalam Q.S.86:5-7: “Hendaknya manusia melihat dari apa ia diciptakan. Ia diciptakan dari air yang memancar di antara tulang sulbi dan tulang dada”.

Dengan materi dasar air inilah, maka tubuh manusia sebagian besar (80\%) terdiri dari air, dan manusia tidak akan bisa hidup tanpa air. Sayangnya, tidak semua manusia menyadari akan pentingnya pelestarian air bagi kehidupan mereka. Hal ini terwujud dalam tindakan-tindakan yang merugikan dirinya sendiri, seperti menebang pohon secara liar sehingga mengurangi daerah tangkapan air (catchment area), membuang sampah di sungai, dan boros dalam penggunaan air.

Perilaku tersebut di atas mendatangkan bencana seperti banjir, tanah longsor, dan kekeringan. Allah SWT menjelaskan bahwa bencana tersebut tidak lain adalah akibat ulah mereka sendiri. Ia berfirman: Artinya: "Telah tampak kerusakan di darat dan di laut akibat perbuatan tangan-tangan manusia, agar mereka merasakan akibat sebagian dari yang mereka lakukan, agar mereka kembali (ke jalan yang benar)”. Allah SWT juga menyatakan bahwa bukanlah manusia yang menangkap dan menyimpan air yang diturunkan Allah dari langit. Manusia tidak akan sanggup untuk menjalankannya. Tugas untuk menangkap dan menyimpan air ini diberikan kepada tumbuhan. Al-Qur'an menyatakan dalam Q.S.15:22: “Dan kami telah meniupkan angin untuk mengawinkan (tumbuh-tumbuhan) dan kami turunkan hujan dari langit, lalu kami beri minum kamu dengan air itu, dan sekali-kali bukanlah kamu yang menyimpannya”. Pada ayat tersebut, tersirat bahwa manusia dapat dengan mudah untuk mendapatkan air jika di lingkungan manusia tinggal terdapat tumbuhan. Oleh karena itu, manusia hendaknya mampu melestarikan keberadaan lingkungan dengan tidak menebang pohon sembarangan dan terus melakukan penanaman pohon baru.

Nabi Muhammad SAW melarang manusia untuk memotong pohon sidrah (nama sebuah pohon yang tumbuh di jazirah Arabia). Beliau bersabda: "Barang siapa yang menebang pohon sidrah maka Allah akan meluruskan kepalanya tepat di neraka" (H.R. Abu Dawud). Inilah ancaman Nabi Muhammad SAW bagi siapa saja yang menebang pohon secara liar. Pohon Sidrah bagi masyarakat di tanah Arab sangat penting sebagai tempat berteduh bagi manusia ataupun hewan, dan tent unya sebagai penampung air. Sebaliknya, Nabi Muhammad 
SAW sangat menganjurkan umat Islam untuk menanam pohon sebanyakbanyaknya yang akan menjadi sedekah mereka. Ia bersabda: "Tidaklah ada seorang muslim yang menanam tanaman dan kemudian ada burung, atau manusia, atau binatang lain, makan dari tanaman tersebut kecuali ia adalah sedekah untuknya" (H.R. al-Bukhari, Muslim dan Imam Ahmad) (Foltz, 2003).

Kearifan berbasis agama ini dapat mendorong pemeluknya untuk setia melestarikan alam, karena hal itu dipandang sebagai tunt utan agama yang sifatnya suci. Agama mengatur tat cara penghormat an terhadap alam, sebagai bentuk rasa syukur manusia at as karunia-Nya.

\section{Bentuk-bentuk Kearifan Lokal di Kecamatan Sempor}

Bentuk-bentuk kearifan lokal yang hidup di Kecamatan Sempor tersebar di tiga desa, yakni Desa Somagede, Kenteng, dan Kedungjati. Di tiga desa ini, kearifan lokal itu mempunyai pola-pola yang berbeda.

\section{Desa Somagede: Belik Banyudana dan Ritual Bersih Desa}

Di Desa Somagede, kearifan lokal itu berupa mitos dan folklore Belik Banyudana. Di sekitar belik ini terdapat pohon Jati yang hingga saat ini berdiri kokoh dan tidak boleh ditebang dengan alasan apa pun. Salah satu mitos yang eksis di sini bahwa belik tersebut tidak pernah kering sejak dibuat hingga sekarang ini. Meskipun di beberapa sumber mata air lain kekeringan, belik ini tetap saja penuh dengan air. Di saat mata air yang lain kering di musim kemarau, belik ini adalah tumpuan masyarakat untuk memenuhi kebutuhan air mereka, khususnya bagi mereka yang tidak memiliki sumur gali. Selain itu, air belik ini juga dapat menyembuhkan penyakit. Keadaan ini dianggap oleh warga setempat sebagai keajaiban pada belik tersebut.

Mitos ini bisa dimaknai sebagai upaya masyarakat untuk melindungi sumber air yang mereka miliki. Mitos tentang air belik Banyudana yang tidak pernah habis sangat terkait erat dengan mitos kekeramatan pohon jati di atas belik tersebut. Dalam ilmu Hidrologi (ilmu tentang air), air tentu saja membutuhkan tempat resapan atau yang bisa disebut dengan catchment area, yaitu berupa daerah pepohonan. Jika pepohonan itu ditebang dan gundul, maka air tentu saja tidak memiliki tempat untuk singgah sehingga kuantitas air berkurang bahkan habis. Lestarinya pohon Jati sebagai hasil dari mitos yang diciptakan oleh masyarakat Somagede berbuah lestarinya belik Banyudana.

Selain itu, di Desa Somagede terdapat ritual tahunan yang diadakan pada bulan Sya'ban, yakni Ritual Bersih Desa. Bersih Desa adalah sebuah ritual dalam masyarakat kita. Bersih Desa merupakan warisan dari nilai-nilai luhur lama 
budaya yang menunjukkan bahwa manusia jadi satu dengan alam. Ritual ini juga dimaksudkan sebagai bentuk penghargaan masyarakat terhadap alam yang menghidupi mereka.

Acara ritual Bersih Desa ini biasanya berlangsung satu kali dalam setahun. Acara ini dibagi dalam serangkaian acara. Hari pertama biasanya dikhususkan untuk ritual sesaji dan persiapan-persiapan segala hal untuk hari berikutnya. Sesaji ditaruh di titik yang meliputi pusat-pusat desa, tempat-tempat keramat, tempat-tempat yang berkaitan dengan air (sumur, sungai, mata air), batas-batas desa (utara, selatan, timur, barat), setiap perempatan, dan setiap pertigaan di wilayah tersebut. Hari kedua, acara berisikan kesenian-kesenian budaya lokal. Acara-acara seperti warok, kuda lumping, dan tari-tarian mendominasi. Di hari ini pula, ada acara makan bersama. Setiap warga memasak makanan masingmasing, lalu dibawa ke tempat berlangsungnya acara kesenian, dan makan bersama-sama.

Jika memakai perspektif (sudut pandang) budaya, dalam konsep pelestarian, ritual hajat bumi dilakukan sebagai langkah untuk terus mempertalikan tradisi yang turun-temurun diterima warga. Masyarakat Jawa dikenal sebagai masyarakat yang religius. Perilaku kesehariannya dipengaruhi oleh pemikiran spiritualitas berada dalam lingkup ruang kosmos. Dalam hal ini, relasi kehidupan masyarakat Jawa mempunyai hubungan istimewa dengan alam.

Dalam sejarah kehidupan dan alam pikiran masyarakat Jawa, alam di sekitar masyarakat sangat berpengaruh dalam kehidupan sehari-hari. Alam sangat mempengaruhi pola pikir masyarakat, bahkan dalam mata pencaharian mereka. Sebagai contoh yang sangat sederhana, musim sangat berpengaruh pada mata pencaharian bercocok tanam. Mungkin karena kedekatan masyarakat terhadap alam pula yang menyebabkan berkembangnya pemikiran mengenai fenomena kosmogoni dalam alam pemikiran masyarakat Jawa, yang kemudian melahirkan beberapa tradisi atau ritual yang berkaitan dengan penghormatan terhadap alam tempat hidup mereka (Focus Group Discussion, 7 Juli 2010).

Pentingnya ritual desa di atas memang sering disalahpahami oleh sebagian masyarakat modern sebagai takhayul, termasuk oleh anak-anak muda Somagede yang telah memperoleh pendidikan tinggi. Keadaan ini disesalkan oleh Pak Warsimin (37), yang menggambarkan mereka sebagai "anak-anak muda yang tidak lagi menghargai tradisi". Akibatnya, ritual yang sebenarnya bertujuan untuk menanamkan nilai-nilai keterkaitan manusia dengan alam diabaikan begitu saja. Alam yang seharusnya menjadi 'sahabat' manusia berubah seperti benda mati yang tidak ada pengaruh apa pun bagi kehidupan manusia. Pikiran 
seperti ini, menurut Warsimin, menyebabkan munculnya bencana alam sebagai akibat langsung dari kepongahan manusia terhadap alam.

\section{Desa Kenteng: Menebang-menanam, Gebas Kuburan, dan Slametan Desa}

Salah satu kesepakatan di Desa Kenteng adalah kewajiban untuk menanam minimal satu pohon bagi siapa saja yang akan menebang pohon yang sudah besar. Maksudnya, jika seseorang hendak menebang pohon di pekarangannya, ia harus sudah menyiapkan calon pohon penggantinya. Hal ini sudah menjadi tradisi warga masyarakat setempat secara turun-temurun guna menjaga kelestarian lingkungan. Hasilnya, seperti pengamatan penulis ketika mengadakan survei lapangan di sana, kondisi lingkungan alam di desa tersebut terasa sangat asri dan sejuk, suatu kondisi yang biasa kita rasakan ketika kita berada dalam lingkungan pegunungan dan hutan. Walaupun aturan tentang keharusan menanam ketika menebang ini pada pelaksanaannya tidak diawasi secara khusus dan ketat oleh aparat setempat, secara umum dapat dikatakan bahwa hal tersebut telah berhasil dilaksanakan secara baik oleh warga masyarakat setempat. Hal ini tidak terlepas dan tumbuhnya kesadaran umum masyarakat tentang pentingnya kelestarian lingkungan, sehingga sudah menjadi semacam kebutuhan bersama. Walau tidak diawasi, aturan tak tertulis ini pun tetap jalan dan dilaksanakan dengan penuh tanggung jawab.

Kesepakatan tak tertulis lainnya yang dirasakan penting dan tetap dijalankan masyarakat setempat adalah menjaga kelestarian sumber mata air. Di desa Kenteng terdapat beberapa sumber mata air, di samping keberadaan sungai yang melintas mengelilingi desa tersebut. Keberadaan sumber mata air dan sungai menjadi sumber vital untuk memenuhi kebutuhan air sehari-hari bagi warga masyarakat. Masyarakat setempat juga menggunakan sumur-sumur buatan untuk memasok kebutuhan air sehari-hari. Pada musim kemarau di mana air sungai jauh berkurang, keberadaan sumber mata air dan sumur-sumur menjadi semakin terasa penting. Masyarakat setempat menyadari bahwa keberadaan sumber mata air dan air sumur tersebut sangat tergant ung pada keberadaan tanaman-tanaman besar. Dalam hal ini, ada sekitar lima (5) buah sumber mata air permanen (tidak mengalami penurunan debitnya walau di musim kemarau) yang di sekitarnya tumbuh pohon besar berumur puluhan bahkan ratusan tahun. Salah satunya berada di suatu daerah yang bernama "pesucen" (artinya: tempat bersuci) yang berada di dukuh Kuncen. Oleh karenanya, masyarakat berupaya untuk mempertahankan keberadaan pohon-pohon besar tersebut dan mencegahnya dari upaya-upaya perusakan terhadapnya. 
Salah satu upaya untuk melindungi keberadaan pohon-pohon tersebut sekaligus menjaga kelestarian sumber daya air di desa setempat, masyarakat mempertahan mitos-mitos tentang "kekeramatan" pohon-pohon tersebut.

Bentuk ritual masyarakat Desa Kenteng yang ada kaitannya dengan kepedulian alam adalah acara gebas kuburan (bersih-bersih makam) dan slametan desa. Acara gebas kuburan diadakan dua kali dalam setahun, yaitu pada bulan Syura (disebut juga Syuronan) dan bulan Rajab. Tradisi gebas kuburan ini sudah berlangsung secara turun-temurun dan dalam pelaksanaannya mengalami perubahan seiring dengan perubahan yang terjadi di kalangan masyarakat desa Kenteng.

Menurut penuturan Mbah Abu Nasir, pada zaman dulu sebelum kepala desa dijabat oleh Bapak Imam Baihaki, acara gebas kuburan pada bulan Syura diisi dengan kerja bakti bersih-bersih makam desa, lalu pada malamnya dilanjutkan dengan slametan desa. Sesuai dengan namanya, acara ini dimaksudkan untuk mengharap keselamatan bagi semua penduduk desa dan juga sebagai bentuk syukur atas kenikmatan yang telah diberikan Tuhan kepada mereka. Dengan lain kata, acara slametan desa dimaksudkan untuk membersihkan unsur-unsur negatif dan energi merusak dari lingkungan desa. Acara diisi (model dulu) dengan penyembelihan seekor kambing lalu kepalanya dikubur di perempatan jalan desa dan sisanya dimasak untuk dinikmati bersama. Acara juga diisi dengan doa bersama yang dipimpin oleh tokoh desa (semacam modin) yang ditujukan kepada Gusti Kang Murbeing Dumadi dan juga danyangdanyang desa. Namun, semenjak kepala desa dijabat oleh Bapak Imam Baihaki, praktik mengubur kepala kambing dihapus. Kambing yang disembelih dimasak semua dan dinikmati bersama dalam acara slametan tersebut. Selanjutnya, acara gebas kuburan pada bulan Syura ini ditutup dengan hiburan Tayub (ledek) semalam suntuk sebagai hiburan yang ditunggu-tunggu masyarakat setempat.

Adapun acara gebas kuburan pada bulan Rajab diisi dengan kerja bakti bersih-bersih makam desa pada siangnya, dan pada malamnya diisi pengajian umum dengan mendatangkan muballigh dari luar desa. Acara pengajian ini juga merupakan inisiatif dari kepala desa Imam Baihaki yang sebelumnya tidak pernah ada selama bertahun-tahun.

Bila kita cermati, kegiatan gebas kuburan dan slametan, atau di tempat lain disebut dengan sebutan yang berbeda seperti bersih desa, selamatan merti desa dan lainnya, pada hakikatnya merupakan bentuk ucapan syukur kepada Tuhan Yang Maha Esa atas segala limpahan rahmat dan karunia yang dicurahkan kepada kita, sekaligus guna memohon keselamatan dari Yang Maha Kuasa bagi segenap warga desa, yang merupakan ritual warisan dari nilai-nilai luhur budaya 
bangsa yang menunjukkan bahwa manusia menyatu dengan alam. Ritual ini juga bisa diartikan sebagai ungkapan pernyataan masyarakat terhadap identitas, akar budaya, dan idealisme melalui pengalaman otentik orisinal komunitas, yakni komunitas menjadi pencipta budayanya sendiri.

Di dalam acara selamatan ini, setiap orang berada dalam keselarasan, karena masyarakat tidak lagi dibedakan antara satu dengan yang lain, tidak dipandang lebih rendah atau lebih tinggi. Bersih desa sebagai salah satu bentuk dari kegiatan selamatan, mempunyai ciri khas sendiri dibandingkan dengan yang lain. Hal ini karena bersih desa memiliki dimensi yang lebih luas, berkaitan erat dengan dimensi sosial dalam suatu desa tertentu. Maka dari itu, pentingnya untuk mengadakan acara bersih desa kadangkala tidak mudah untuk ditawartawar, karena merupakan sebuah wahana atau sarana di mana seluruh warga desa dapat berinteraksi sosial satu sama lain secara lebih intensif.

Upacara adat bersih desa ini secara umum memang untuk meminta keselamatan dan kesejahteraan kepada Yang Maha Agung. Dalam kenyataannya, masyarakat masih kuat mempercayai "kekuatan gaib", termasuk arwah nenek moyang atau leluhur. Masyarakat akan merasa tenang setelah melakukan upacara adat tersebut karena dengan demikian mereka akan memperoleh keselamatan dan "kekuatan" yang dianggap melebihi kekuatan diri sendiri. Dalam hal ini, masyarakat harus mengadakan upacara walaupun hanya sederhana, sebab kalau sampai tidak menjalani upacara, orang akan merasa khawatir atas keselamatannya.

Di samping itu, acara gebas kuburan (slametan desa) di atas juga menyimpan nilai-nilai kearifan lokal dalam pelestarian dan pemeliharaan terhadap lingkungan. Betapa tidak, minimal dua kali dalam setahun masyarakat secara bersama melakukan tindakan nyata membersihkan lingkungan makam dan tempat-tempat khusus yang dianggap sakral. Tempat-tempat tersebut dianggap sebagai warisan leluhur yang harus dilestarikan. Tempat yang sakral itu dianggap memiliki tuah atau daya tertentu. Acara ini juga menyampaikan pesan kepada segenap masyarakat untuk memelihara kebersihan dan kenyamanan lingkungan, terutama pada moment-moment penting seperti bulan Syura/ Muharram (tahun baru Jawa/Islam) dan bulan Rajab, yakni dalam rangka menyambut bulan puasa/Ramadan).

Acara ini pada dasarnya merupakan hajatan besar desa. Hajatan dilakukan secara kolektif, dengan biaya ditanggung bersama, dan diikuti seluruh warga desa, pria-wanita, tua-muda, bersama pamong dan pejabat setempat. Hajatan juga diikuti oleh warga dari tetangga sebelah. Secara lebih luas, ritual gebas kuburan ini pada dasarnya bertujuan untuk menjadikan desa tersebut bersih, 
tertib, teratur, dan terawat baik, sehingga dapat "ikut menjaga" ketahanan desa agar menjadi lebih maju dan lestari.

Ringkasnya, ritual gebas kuburan yang dilakukan masyarakat Desa Kenteng kini nuansanya agak berbeda dengan model dulu. Unsur-unsur sesajen sudah dihilangkan, sebaliknya nilai-nilai Islam lebih ditonjolkan, yakni dengan ditambahkannya acara pengajian umum. Namun demikian, kearifan lokal yang berhubungan dengan pelestarian alam tetap melekat di dalamnya. Hal ini tentunya sangat positif mengingat wilayah tersebut merupakan daerah perbukitan dan aliran sungai yang memiliki risiko kerusakan lingkungan sangat besar jika tidak betul-betul dijaga kelestariannya oleh seluruh warga masyarakat.

\section{Desa Kedungjati: Mitos Sunan Buyut Saringan}

Di Desa Kedungjati terdapat mitos dan folklore yang tersebar luas di kalangan masyarakat desa, yaitu tentang makam Sunan Buyut Saringan. Makam tersebut memiliki telaga atau sumber air yang masih digunakan warga hingga saat ini, yaitu dengan cara mengalirkan airnya melalui selang-selang kecil ke rumah-rumah mereka.

Menurut cerita masyarakat setempat, sebagaimana diceritakan Pak Aris Sukmantoro (39), Sunan Buyut Saringan adalah salah satu prajurit Pangeran Diponegoro yang dijadikan mata-mata dengan menyamar menjadi orang biasa dan tinggal di wilayah Kedungjati. Ia membuat tempat beribadah dan tempat bersucinya yang berupa sendang yang digunakan oleh masyarakat sampai saat ini untuk salat ketika berkunjung ke makam tersebut. Jika dilihat dalam teori antropologi, khususnya tentang konsep culture hero, atau pahlawan budaya, Sunan Buyut Saringan bisa jadi adalah pahlawan budaya yang memiliki pengaruh kuat dalam kehidupan masyarakat Kedungjati. Menurut Anna-Teresa Tymieniecka pahlawan budaya adalah seseorang yang mula-mula menemukan atau melestarikan tradisi masyarakat setempat, menamai nama-nama pohon, binatang atau tempat, mengajari masyarakat dan akhirnya tradisi yang ditinggalkannya diikuti oleh masyarakat sesudahnya (Tymieniecka, 2004: 650).

Mitos yang berkembang dalam masyarakat menyebutkan bahwa air di telaga Buyut Saringan memiliki tuah yang memberikan banyak khasiat bagi yang mandi atau yang meminumnya. Menurut Pak Aris, banyak orang luar yang datang ke makam Sunan Buyut Saringan dan mandi di sendangnya sebelum berdoa di makam. Dalang-dalang yang akan pentas di Kedungjati, semuanya mandi di telaga makam Buyut Saringan sebelum memulai pentasnya.

Masyarakat Kedungjati mempercayai bahwa dalang-dalang yang pentas di Kedungjati, setelah terlebih dahulu ke makam Buyut Saringan, akan semakin 
masyhur. Pak Aris bercerita tentang Ki Manteb Sudarsono. Dia berkisah bahwa suatu ketika Ki Manteb akan pentas di Kedungjati. Dia datang jam 10 malam, dan langsung berangkat ke makam. Sesampainya di gerbang makam, Ki Manteb tiba-tiba berjalan jongkok sebagaimana laiknya seseorang yang akan menghadap raja. Sampai di makam, ia lantas berwudhu lalu salat. Ketika pulang dari makam pun Ki Manteb kembali jalan sambil berjongkok. Ketika ia pentas di Lampung, orang-orang Kedungjati mendengar kabar bahwa Ki Manteb mengatakan dalam pentasnya bahwa ia telah mengunjugi sebuah istana di Gombong. Pada kaitan ini, terdapat kepercayaan masyarakat bahwa setiap orang yang berwudhu di telaga dekat makam itu mesti akan bertemu dengan ular "weling", sebagai pengeling-eling untuk selalu berbuat baik. Para pengunjung makam pun tidak boleh kencing di sendang, berbicara sembarangan, atau merusak pepohonan yang ada di sekitar sendang.

Folklore dan mitos yang berkembang dalam masyarakat Kedungjati ini tent unya memiliki makna positif bagi kelestarian sumber daya air. Keramatnya sendang, yang tidak boleh dikencingi, tidak berkata-kata kotor di sekitar sendang, dan dibersihkan secara berkala oleh masyarakat tentu saja membuat sendang lestari. Perilaku masyarakat yang didasarkan pada mitos maupun folklore Sunan Buyut Saringan akan menjaga kualitas maupun kuantitas air sendang.

\section{E. Simpulan}

Dari hasil uraian mengenai kearifan lokal berbasis Islam dalam melestarikan lingkungan hidup masyarakat Kecamatan Sempor, Kabupaten Kebumen, dapatlah disimpulkan beberapa hal berikut. Pertama, mitos yang terlahir dari buah pikir atau sebagai hasil dari imajinasi konstruktif masyarakat terkait erat dengan hubungan antara manusia dan lingkungan alam sekitamya. Kedua, bentuk kearifan lokal yang berupa kesepakatan, pengetahuan, at uran lokal, mitos, dan hubungan dengan Tuhan memiliki peranan yang sangat penting dalam pelestarian lingkungan hidup, khususnya sumber daya air. Ketiga, kesepakatan-kesepakatan tak tertulis yang sudah berlangsung selama puluhan tahun dan seolah telah menjadi hukum tetap, dan memiliki pengaruh positif dengan kehadiran dari Sunan Buyut Saringan yang memberikan nasihat untuk menjaga lingkungan melalui selametan dan nilai-nilai Islam. 


\section{Daftar Pustaka}

Abdillah, Mujiyono. 2001. Agama Ramah Lingkungan: Perspektif al-Qur'an. Jakarta: Paramadina.

Arikunto, Suharsimi. 2007. Prosedur Penelitian: Suatu Pendekatan Praktek. Jakarta: Rineka Cipta.

Ayatrohaedi. 1986. Kepribadian Budaya Bangsa (Local Genius). Jakarta: Pustaka Jaya.

Fauzi, Ihsan Ali. 1994. "Kearifan Tradisional dan Bumi Manusia", dalam Jurnal Dialog Pemikiran Islam Islamika, No. 3, Januari-Maret 1994.

Geriya, S. Swarsi. 2008. "Menggali Kearifan Lokal untuk Ajeg Bali" dalam balipos.co.id diakses pada 4 Februari 2009.

Geertz, Clifford. 1973. The Interpretation of Culture. New York: Basic Books, Inc., Publishers. versity of Chicago Press. 1983. Local Knowledge. New York: Basic Books.

Gobyah, I Ketut. 2008. "Berpijak pada Kearifan Lokal” dalam balipos.co.id, diakses pada 4 Februari 2009.

Irianto, Agus Maladi. 2010. "Saresehan Kearifan Lokal Provinsi Jawa Tengah", Bahan diskusi yang disampaikan Di Hotel Telomoyo Semarang yang diselenggarakan tanggal 29 Januari 2009 oleh Badan Kesbangpol dan Linmas Prov. Jateng dalam http://staff.undip.ac.id, diakses pada tanggal 4 Februari 2010.

Odum, Eugene P. 1983. Basic Ecology .USA: Sounders College Publishing. Sukmadinata, Nana Syaodih. 2006. Metode Penelitian Pendidikan. Bandung: Remaja Rosdakarya.

Syam, Nur. 2005. Islam Pesisir. Yogyakarta: LKiS.

Thohir, Mudjahirin. 2006. Orang Islam Jawa Pesisiran. Semarang: FASINDO. Wacana, Petrasa. 2010. "Kebudayaan dan Kearifan Lokal dalam Mengelola Lingkungan dan Sumberdaya Air Kawasan Kars Gn. Sewu”, dikutip dari http://www.psmbupn.org/, diakses pada tanggal 4 Februari 2010. 